\title{
Aktiv mestring i hjemmesykepleien
}

\author{
Hverdagsrehabilitering gjør brukerne mindre avhengige av hjelp samtidig som \\ de ansatte opplever jobben som mer meningsfylt.
}

$\mathbf{R}$ ehabilitering i hjemmet har stått på agendaen i flere kommuner de seineste årene. Bakgrunnen for dette er ikke minst erfaringer fra Östersund Kommune i Sverige og Fredericia Kommune i Danmark (1-3). Resultatene derfra viser at ved å fokusere mer på rehabilitering blir mottakere av hjemmesykepleie mindre avhengig av hjelp, og de ansatte opplever at de gjør en mer meningsfull jobb. I tillegg blir det frigjort ressurser i form av tid og penger (1-3).

\section{Hverdagsrehabilitering}

I kjølvannet av dette har det oppstått en ny form for rehabilitering; hverdagsrehabilitering.

\section{Hovedbudskap}

Flere forhold har ført til større fokus på rehabilitering i hjemmetjenesten. Hverdagsrehabilitering lanseres derfor som en ny type rehabilitering spesielt for rehabilitering i pasienters eget hjem. Det vil imidlertid kreve mer tverrfaglig samarbeid og samhandling.

\section{Nøkkelord}

Les mer og finn litteraturhenvisninger på våre nettsider. \) Hjemmesykepleie \ Rehabilitering | Tverrfaglighet
Dette dreier seg primært om rehabilitering i hjemmet i tilknytning til den hjelpen som ytes av hjemmetjenesten. Det som særkjenner hverdagsrehabilitering er at de som mottar hjelp selv bidrar aktivt til å opprettholde eller bedre egen funksjon. For de ansatte innebærer det en dreining fra stor grad av kompenserende tiltak til vektlegging av aktivisering og egen mestring av hverdagen i eget hjem (1,4-7). Man må derfor i større grad ha en rehabiliterende holdning med vekt på en støttende, heller enn bare en hjelpende innstilling. En slik tilnærming involverer og ansvarliggjør mottaker i større grad, og man kan vekke interesse for egne muligheter og ressurser og oppmuntre til egen problemløsning og handling (8). I stedet for stadig å være på tilbudssiden ved å spørre om hva den enkelte trenger hjelp til, spør man heller: «Hva er viktige aktiviteter for deg nå?» og om hvordan den eldre hjemmeboende kan trene for å opprettholde og bedre egen funksjon (7). Sånn sett er hverdagsrehabilitering både et tankesett og en arbeidsform. Tidlig tverrfaglig kartlegging og intervensjon er sentralt, samt kravet til at rehabiliteringen skal være planlagt i form av en plan med klare mål og tiltak (9). Hverdagsrehabilitering vektlegger både nye brukere og ny eller løpende vurdering av de som har hatt hjelp over tid $(2,3)$.

\section{Samhandling}

I Norge har fokuseringen på hverdagsrehabilitering skutt fart med innføring av samhandlingsreformen i 2012. Reformen har også ført til at det har blitt gjennomført og pågår en rekke rehabiliteringsprosjekter (10-13). I Helse Fonna-området, som er en del av Helse Vest, har det blant annet foregått flere rehabiliteringsprosjekter som samarbeid mellom helseforetaket, Høgskolen Stord/Haugesund og noen kommuner. Det første prosjektet, som var et kartleggingsprosjekt i et sykehus og i en større kommune, viste at rehabiliteringsaktiviteten både i hjemmetjenesten og i de vanligste medisinske og kirurgiske avdelingene, var svært lav (Birkeland 2012). Også graden av undervisning i rehabilitering på bachelorutdanningen $\mathrm{i}$ sykepleie i høyskolen var lav. Flere andre prosjekter viser imidlertid at det er mulig å øke rehabiliteringsaktiviteten i hjemmetjenesten hvis man fokuserer på rehabilitering (11-13). Mye tyder på at pasientene kan få betydelig høyere funksjonsnivå og en opplevelse av å delta mer, forutsigbarhet og tettere oppfølging.

\section{Barrierer}

Selv om betydningen av hverdagsrehabilitering er vel dokumentert, er likevel sykepleiere beskrevet som den yrkesgruppen som har hatt 
størst vansker med å tilpasse seg hverdagsrehabilitering i praksis (1-3). I Fredericia Kommune i Danmark hadde hjemmesykepleien så store holdningsmessige barrierer at de etablerte en egen enhet som utelukkende arbeider med rehabilitering (3). Man skal heller ikke underslå at det er andre yrkesgrupper, spesielt ergoterapeuter og fysioterapeuter, som har vært mest aktive i å dreie tjenester i hjemmet mot aktivering og selvhjelp. Det reiser spørsmål om i hvilken grad rehabilitering kan knyttes til sykepleie som fag og profesjon, og ikke minst til hjemmesykepleie som eget fagområde.

\section{Må motiveres}

Rent juridisk sett er rehabilitering tungt begrunnet. Forskriften er sentral og krever avgrensing i tid, klare mål, tiltak og tverrprofesjonelt samarbeid. Det kreves også at pasienter og eventuelt pårørende samarbeider og deltar for at vi skal kunne definere et opplegg som

\section{«Omsorg står ikke i noe motsetningsforhold til rehabilitering.»}

rehabilitering (9). Rehabilitering er å betrakte som helsehjelp og er dermed en rettighet jamfør pasientrettighetsloven og helse og omsorgstjenesteloven $(14,15)$, og framheves ellers i verdighetsgarantien (16). Hjemmesykepleien, og dermed de sykepleierne som arbeider der, er underlagt alle disse lovene og forskriftene. Dersom den som mottar hjemmesykepleie har et rehabiliteringsbehov, har de også rett på rehabilitering. Hjemmesykepleien kan for eksempel ikke unnskylde seg med at de ikke har tid. Det viser seg dessuten at rehabilitering på sikt frigjør tid, noe som gjør tidsaspektet lite holdbart som argument mot rehabilitering. Andre argumenter mot rehabilitering kan for eksempel være at pasienten ikke er motivert for å trene eller gjøre noe selv, men nettopp derfor er motivasjon et viktig element i all rehabilitering. Rehabilitering er derfor i stor grad noe man må motiveres til, og manglende motivasjon kan derfor i utgangspunktet ikke brukes som et argument mot rehabilitering.

\section{Grunnfunksjon}

Hvis vi går tilbake til sykepleiens grunnprinsipper må vi heller ikke glemme at Virginia Henderson poengterer viktigheten av å hjelpe pasienter med å ivareta sine grunnleggende behov. Men hun sier også at hjelpen skal gis på en slik måte at pasienten kan, hvis mulig, gjenvinne uavhengighet så snart som mulig (17). Det ligger derfor i sykepleiens grunnfunksjon å arbeide rehabiliterende (18). Man skal hjelpe og kompensere for funksjonssvikt, ja, men implisitt i dette ligger å hjelpe pasienten til å kunne hjelpe seg selv. Det er også veldokumentert at spesielt eldre er opptatt av å være uavhengige av hjelp så lenge som mulig $(19,20)$. Å si at hjelp til selvhjelp i mange henseender kan være det beste for dem som mottar hjemmesykepleie er derfor velbegrunnet.

\section{Omsorg}

Spørsmålet er imidlertid om å utøve hjemmesykepleie i for stor grad har blitt å hjelpe og kompensere, på bekostning av å bidra til at brukere kan hjelpe seg selv i størst mulig grad. En del forhold kan tyde på det, og det kan ha ulike årsaker. For eksempel kan det være et resultat av en delvis misforstått omsorg der det å hjelpe så mye som mulig blir et mål i seg selv. Men omsorg handler om den gode og vennlige kontakten og at den praktiske utførelsen skal være preget av respekt. Ifølge Kari Martinsen har omsorg også en moralsk dimensjon ved at de som trenger mest hjelp, inkludert rehabilitering, også blir prioritert $(21,22)$. På den måten vil omsorg være en viktig etisk rettesnor også for rehabiliteringsarbeidet. Omsorg handler derfor nødvendigvis ikke om å frata pasienter eller brukere muligheter for at de skal kunne greie seg mest mulig på egen hånd. En artikkel fra Dansk Sundhetsinstitutt (3) bærer tittelen: «Fra pleie og omsorg til rehabilitering». Man kan spørre seg om sykepleiere skal slutte å drive med pleie og omsorg og erstatte det med rehabilitering? Det er i så fall ikke aktuelt. Omsorg står ikke i noe motsetningsforhold til rehabilitering i og med at rehabilitering også skal utøves på en omsorgsfull måte i tråd med helsepersonelloven (23). Omsorg er fortsatt en rettesnor for morgendagens helsetjenester $(5,6)$. For eksempel sies det i verdighetsgarantien at «omsorgen skal bidra til rehabilitering» (16). Når det hevdes at man må bevege seg fra pleie og omsorg til rehabilitering, så mener man nok at man må fokusere sterkere på rehabiliteringselementet. Hvis ikke står man i fare for å gi mer pleie og omsorg enn det som er nødvendig. Det er dette som også kalles overpleie eller «hjelpefelle» $(3,24)$. Vi kan også notere oss betegnelser som «hemmelige tjenester» (25) som beskriver at noen ansatte i hjemmetjenesten gir hjelp langt utover det som er avtalt og innvilget, og som kan bidra til passivitet, hjelpeløshet og avhengighet.

\section{Økonomi}

Andre årsaker til at Norge noen steder ligger litt etter Sverige og Danmark når det gjelder hverdagsrehabilitering, kan være at den økonomiske situasjonen i Norge har vært bedre enn i disse landene. Kombinert med økt bevissthet om de rettigheter og krav man har på hjelp, kan dette ha ført til at hjemmetjenesten ikke har hatt dekning for å kreve mer egentrening og egenaktivitet av brukerne sine. Sykepleiere har også uttalt at når en person får innvilget hjemmesykepleie, forventes det nærmest at pleierne skal overta mest mulig (24). Det blir på en måte et press fra lokalsamfunnet om at hjemmetjenesten skal overta og utøve praktisk hjelp og pleie. På den måten kan det oppstå en ond sirkel med stadig større krav om «å hjelpe» og medfølgende tidspress.

\section{Tverrfaglighet}

Skal det bli mulig å drive med rehabilitering i egentlig forstand, krever det tverrfaglighet (9). I så fall må ikke minst fysio- og ergoterapeuter i større grad involveres i det daglige arbeidet. Ikke fordi selve sykepleien nødvendigvis har vært og blir utført på en dårlig måte, men fordi endringer på ulike nivåer av og til krever at vi endrer og tilpasser den praksisen vi står i til daglig. For eksempel har hjemmesykepleien over tid blitt tilført både flere brukere og mer kompliserte arbeidsoppgaver (6). Den sykepleien som har vært utøvd i hjemmene må i store trekk fortsette som før. Men i noen tilfeller vil det i tillegg være behov for spesiell tverrfaglig vurdering, oppfølging og trening, der for eksempel fysioterapeuter og ergoterapeuter har en mer framtredende rolle. Samtidig ser vi at kommunene ofte er organisert slik at leger, fysioterapeuter, ergoterapeuter og hjemmesykepleiere er organisert i egne separate avdelinger eller enheter som kan gjøre samarbeidet utfordrende. Når noen har behov for rehabilitering tar man gjerne en telefon eller sender en søknad til fysioterapeuten, som så gir individuell behandling et visst antall ganger i uken. Men saken er at det ikke er rehabilitering. Rehabilitering er når ansvarlig sykepleier, fysioterapeut, ergoterapeut og eventuelt flere, sammen med pasient eller bruker, lager en plan for rehabiliteringen der det går fram hva som er den enkeltes oppgaver og ansvar. Hjemmesykepleiens 
oppgave vil være å vurdere hva slags sykepleie pasienten trenger. Det vil si å vurdere hjelp til grunnleggende behov og alt det medfører, behov for undersøkelser, observasjon og behandling i form av blant annet medisiner. Deretter må man, sammen med pasient eller bruker og andre faggrupper, finne fram til hvordan sykepleien skal innpasses i det totale rehabiliteringsopplegget.

\section{Kjernekompetanse}

Hjemmesykepleie har tradisjonelt vært forbundet med stor faglig selvstendighet, der hjemmesykepleiere og annet pleiepersonell mer og mindre har rådet grunnen alene. Økt nærvær av andre fagprofesjoner kan føre til at faglig selvstendighet og styring av eget fagområde oppleves som truet. I et tverrprofesjonelt samarbeid snakker vi om felleskompetanse, overlappende kompetanse og fellesoppgaver. Det er altså en del oppgaver som flere fagprofesjoner har kompetanse til å kunne utføre, men så er der en del oppgaver, såkalte primæroppgaver, som krever såkalt kjernekompetanse som kun den enkelte faggruppe kan og bør utføre (26). Rehabilitering er avhengig av at ulike profesjoner blir enige om en arbeidsfordeling tilpasset hver enkelt pasient eller bruker. Det kan medføre at sykepleiere og annet pleiepersonell $i$ en viss grad utfører treningsoppgaver, og det kan medføre at fysioterapeuter og ergoterapeuter i en viss grad utfører pleieoppgaver. Vi ser at fysioterapeuter og ergoterapeuter ikke har kapasitet til å utføre all treningen det etter hvert er behov for i hjemmetjenesten. Slik sykepleiere samarbeider med hjelpepleiere, helsefagarbeidere

\section{«Skal det bli mulig å drive med reha- bilitering i egentlig forstand, krever det tverrfaglighet»}

eller andre i utøvelsen av klinisk sykepleie, vil også fysioterapeuter ha behov for å samarbeide med hjelpepleiere eller helsefagarbeidere som «hjemmetrenere». Dette vil imidlertid kreve tid og nødvendig opplæring.

\section{Etiske utfordringer}

Hverdagsrehabilitering er et område som har fått fornyet fokus basert på forskning, utviklingsarbeid og erfaring. Dette kan innebære organisatoriske, metodiske, holdningsmessige og tankemessige endringer i utøvelsen av hjemmesykepleie. Noen kaller det et paradigmeskifte, altså en helt ny måte å forholde seg til og utøve arbeidet på $(2,3,6)$. Men det er neppe grunn til å hevde at dette representerer noe helt nytt. Man kan heller si at man av ulike grunner har fokusert for lite på rehabiliteringsaspektet, på tross av at rehabilitering er og skal være en integrert del av hjemmesykepleien. Det er derfor ikke snakk om å innføre noe helt nytt, men å fokusere mer på en del av hjemmesykepleien som kanskje ikke har blitt vektlagt nok. Man må sånn sett spørre seg selv om vurderingen av rehabiliterings- og hjelpebehov er grundig nok. Blir vurderingen for eksempel gjort tverrfaglig når det er behov for det? Og har man et systematisk samarbeid med pasient eller bruker og pårørende? Får brukerne alltid den opptreningen eller rehabiliteringen de trenger? Har hjemmetjenesten tilstrekkelig tilgang til fysioterapi- og ergoterapitjenester i møte med kompliserte og sammensatte problemstillinger ute i hjemmene? Gjør hjemmetjenesten jevnlige, og ved behov; tverrfaglige evalueringer av hjelpen hver enkelt pasient mottar? Svarene på dette vil variere fra virksomhet til virksomhet, men det er viktig at spørsmålene blir stilt.

\section{Avslutning}

Hverdagsrehabilitering kan begrunnes økonomisk ved at det kan bidra til at flere ikke trenger hjelp eller trenger mindre hjelp, men det er viktig at økonomi ikke blir den eneste begrunnelsen for hverdagsrehabilitering. Hvis ansatte i hjemmetjenesten nå skal prøve å få brukerne til å gjøre mer selv, er det også viktig at den det gjelder er medvirkende på en systematisk og tverrfaglig måte. I motsatt fall blir rehabilitering gjort til noe den enkelte ansatte gjør med den enkelte pasient eller bruker, men det er ikke rehabilitering. Rehabilitering kan være et godt tiltak for mange, men hverdagsrehabilitering er ikke et gode i alle sammenhenger (4). Hjemmesykepleie er et mangfoldig fagfelt med varierte arbeidsoppgaver der den unike pasient eller bruker i sitt hjem er i sentrum. Samtidig er det mange som opplever et funksjonsfall eller som står i fare for å få det. Nettopp disse kan være i behov for rehabilitering bygget på tverrfaglig innsats der den det angår selv medvirker. Hverdagsrehabilitering går ut på å oppdage slike pasienter og iverksette rehabilitering slik at de kan fungere optimalt ut ifra sine egne forutsetninger. Rehabilitering er derfor en viktig del av fagfeltet hjemmesykepleie og bør få større oppmerksomhet. IIII
REFERANSER

Mănsson M Hemrehabilitering:vad, hur och för hvem? Stockholm: Fortbildning AB/Tidningen, eldreomsorg, 2007.

2. Kiellber PK Killberg J Ibsen R, Chist ipraksis: E Keninge fra Fredici 2008-2010. Ergoterapeuten 2012:55: 24-8. The E forlinge fra 24-8. Tilgjengelig fra http://www.ergoterapeuten.no/content/download/50625/188923/file/Fredericia.pdf

3. Kjellberg PK, Ibsen R, Kjellberg J. Fra pleje og omsorg til rehabilitering: Erfaringer fra Fredericia Kommune. fhttp://www.etf.dk/fileadmin/bruger_upload/dokumenter/FAG_FORSKNING/Rehabilitering/DSI_evaluering_-_rapport_september_2011.pdf. (Nedlastet: 29.01.14).

4. Haarr KH. Etiske dilemmaer ved hverdagsrehabilitering. Ergoterapeuten 2013;2:24-8.

5. NOU 2011: 11. Innovasjon i omsorg. Oslo: Helse- og omsorgsdepartementet. http://www.regjeringen.no/pages/16597652/PDFS/NOU201120110011000DDDPDFS.pdf

6. St.meld. nr. 29 (2012-2013). Morgendagens omsorg. http://www.regjeringen no/pages/38301003/PDFS/STM201220130029000DDDPDFS.pdf

7. Ness NE, Laberg T, Haneborg M, Granbo R, Færevaag L, Butli H. Hverdagsmestring og hverdagsrehabilitering. Ergoterapeutene, Norsk Sykepleiermestring og hverdagsrehabilitering. Ergoterapeutene, Norsk Sykepleierforbund og Norsk Fysioterapeutforbund. Oslo, 2012. http://Www.netf.no/ content/download/59168/229791/file/R

8. Lindkvist V. Det er ihemmet det skal børja. http://www.aldreicentrum.se/ till-tidskriften/2004-2002/Nr-42002-Samverkan/Det-ar-i-hemmet-detska-borja-/. (Nedlastet: 29.01.14)

9. Forskrift om habilitering og rehabilitering, individuell plan og koordinator (2011). http://www.lovdata.no/cgi-wift/ldles? doc=/sf/sf/sf-20111216-1256. html. (Nedlastet: 29.01.14).

10. Birkeland A, Bakkevold S, Hausken E, Kvinnesland R, Nicolaisen S, Rossebø B. En kartlegging av rehabilitering i Karmøy kommune og Helse Fonna, herunder pasientgruppene og framtidig behov og ansvarsfordeling. http:// brage.bibsys.no/hsh/handle/URN:NBN:no-bibsys_brage_40613 (Nedlastet: 29.01.14)

11. Aasebø K, Rørlien K, Hauken JA, Kupca A, Lindås L, Myklebust S. Delprosjekt i Slagbehandlingskjeden i Bergen. Rapport fra et utviklingsprosjekt, Dag og oppsøkende rehabilitering. Bergen kommune, 2009-2012. https://www.bergen.kommune.no/bk/multimedia/archive/00127/ Evalueringsrapport__127205a.pdf (Nedlastet: 29.01.14).

12. Hustoft M. Stavanger Kommune. Selvstendig, trygg og aktiv. Evaluering av pilotprosjekt - Hverdagsrehabilitering. Stavanger kommune: Avdeling oppvekst og levekår, 2013.

13. Jakobsen IW. Prosjekt hverdagsrehabilitering i bydelene Vestre Aker og Ullern. 01.10.12-30.09.13. Prosjektrapport Oslo kommune. Bydel Vestre Aker og bydel Ullern, 2013. http://www.bydel-vestre-aker.oslo.kommune.no/ getfile.php/bydel\%20vestre\%20aker\%20 (BVA)/Internett\%20 (BVA)/ Dokumenter/Prosjektrapport\%20Hverdagsrehabilitering\%20i\%20Vestre\%20Aker\%200g\%20Ullern\%20bydeler\%2001102013.pdf. (Nedlastet: 29.01.14).

14. Helse- og omsorgsdepartementet 1999. Lov om pasient og brukerrettigheter. http://www.lovdata.no/all/hl-19990702-063.html. (Nedlastet: 29.01.14).

15. Helse og omsorgsdepartementet 2011: Lov om kommunale helse og omsorgstjenester. 2011. http://www.lovdata.no/all/hl-20110624-030.html. (Nedlastet: 29.01.14)

16. Lovdata. Forskrift om en verdig eldreomsorg. 11 des 2010; $\mathrm{nr} .12$ (Verdighetsgarantien). http://www.lovdata.no/for/sf/ho/xo-20101112-1426.html (Nedlastet: 29.01.14)

17. Henderson V, Mellby S, Munkeby AM. Sykepleiens natur: en definisjon og dens konsekvenser for praksis, forskning og utdanning: refleksjoner etter 25 år. Oslo: Universitetsforlaget, 1998.

18. Birkeland A, Flovik AM. Sykepleie i hiemmet. Oslo: Akribe, 2011.

18. Birkeland A, Flovik AM. Sykepleie i hjemmet. Oslo: Akribe, 2011.
19. Hinck S. The Lived Experience of Oldest-Old Rural Adults. Qualitative Health Re

20. Haak M, Fange A, Iwarsson s, Dahlin S. Home as a signification of indipendence and autonomy: Experiences among very old Swedish people. Scandinavian Journal of Occupational Therapy 2007;:16-24.

21. Martinsen K. Omsorg sykepleie og medisin: historisk filosofiske essays. Oslo: Universitetsforlaget, 2003

22. Alvsvåg H, Gjengedal E. Omsorgstenkning: en innføring i Kari Martinsens forfatterskap. Bergen: Fagbokforlaget, 2000.

23. Helse og omsorgsdepartementet 1999: Lov om helsepersonell. http://www. lovdata.no/all/hl-19990702-064.html. (Nedlastet: 29.01.14).

24. Hegli T. A ikke lage pleiepasienter i hjemmet. Balanse mellom avhengighet og uavhengighet hos hjemmeboende eldre pasienter. Norsk Tidsskrift for Sykepleieforskning 2006;8:4,5l-60.

25. Ness NE. Blogg. Ergoterapeutenes nestleder Nils Erik Ness. Ergoterapeutene. Tilgjengelig fra: http://erganen.wordpress.com/ (Nedlastet: 29.01.14).

Willumsen E Tverrprofesionelt samarbeidi praksis ogutdaning Wilumsen E. Tverrprofesjonelt samarbeid i praksis og utdanning i helseog sosialsektoren. I: Willumsen E, red. Tverrprofesjonelt samarbeid. Oslo:
Universitetsforlaget, 2009:24-7.

Fagartikler kan sendes til torhild.apall@sykepleien.no 